\title{
Vargas, Perón e o esporte: propaganda política e a imagem da nação
}

Vargas, Perón and sport:
political propaganda and the image of the nation Maurício Drumond

Os desportos, sobretudo o futebol, exercem uma função social importante. A paixão desportiva tem poder miraculoso para conciliar até o ânimo dos integralistas com o dos comunistas ou, pelo menos, para amortecer transitoriamente suas incompatibilidades ideológicas. (...) É preciso coordenar e disciplinar essas forças, que avigoram a unidade da consciência nacional. (Getúlio Vargas apud Lyra Filho, 1983: 128)

Ao assumirem o poder, Vargas e Perón começaram a colocar em prática propostas que representavam uma nova visão de Estado e de nação. As políticas

Maurício Drumond é doutorando do Programa de Pós-Graduação em História Comparada da Universidade Federal do Rio de Janeiro, Brasil, e membro do Laboratório de História do Esporte e do Lazer (Sport/UFRJ), onde realiza pesquisa sobre a história política do esporte (msdrumond@yahoo.com.br).

Artigo recebido em 29 de junho de 2009 e aprovado para publicação em 27 de agosto de 2009.

Est. Hist., Rio de Faneiro, vol. 22, n. 44, p. 398-421, julho-dezembro de 2009. 
desses governantes em relação ao esporte estavam inseridas em uma característica maior de seus governos, que visava a ampliar a intervenção estatal em diversas dimensões da sociedade, como a saúde, a educação, o serviço social e a distribuição de bens culturais. O esporte estava inserido, então, como mais um entre tantos outros instrumentos de mediação entre Estado e sociedade.

No que se refere à ingerência do governo sobre a sociedade civil, o esporte não foi um caso diferenciado. Ainda assim, tanto no Brasil como na Argentina, a intervenção do regime sobre o esporte pode ser vista como uma inovação para o período, já que pela primeira vez, nos dois países analisados, o Estado designava aparelhos que tinham como objetivo organizar, patrocinar, promover e controlar as atividades esportivas nacionais.

Nos governos de Vargas e Perón, o esporte começou a ser visto como um importante elemento na relação entre o regime e a sociedade. Tal fato não deve ser entendido apenas como uma resposta à crescente popularidade do esporte. Ainda que crescente em seus governos, a massificação do esporte já havia ocorrido muito antes. Talvez a influência dos regimes de Mussolini e Hitler sobre os dois governantes latino-americanos possa apontar para um melhor entendimento dessa nova visão política, uma vez que ambos tiveram uma estreita ligação com o esporte e a sua utilização como propaganda política. ${ }^{1}$

$\mathrm{O}$ alto grau de mobilização popular no varguismo e no peronismo pode ser igualmente visto como um fator relevante nessa visão política do esporte. A criação de uma política de massas nesses governos, com um líder carismático à frente do país, conduzindo a nação a um novo momento de sua história, marcou um momento de reformulação da imagem da nação. Tornou-se então necessária a construção de uma nova identidade nacional, a ser compartilhada pelas massas que se inseriam de forma decisiva na cultura política dos dois países.

\section{O esporte e a imagem da nação}

Tanto Vargas como Perón tinham grande preocupação com a formação da identidade nacional em seus respectivos países. E nesse sentido o esporte teria uma importância estratégica, já que atuaria como um mediador entre indivíduos e identidades. Ao se tornar um símbolo pátrio, o esporte associaria todos os cidadãos sob um mesmo signo, sob uma mesma comunidade imaginada (Anderson, 2005). No imaginário de cada cidadão há um sentimento comum de pertencimento à sua comunidade - seja essa seu país, sua cidade ou seu clube -, que advém do compartilhamento de vários símbolos, como idioma, hino nacional, bandeira, e muitos outros, entre os quais podem-se citar os esportes. 


\section{Maurício Drumond}

Assim, a identificação dos governos com os esportes seria um importante instrumento na construção de uma identificação da nação. E Vargas e Perón não poupariam esforços para associar seus regimes aos esportes nacionais.

Eduardo Archetti aponta que, na Argentina, os dez anos de governo peronista constituíram o auge da relação entre o Estado e a prática esportiva, através de "políticas estatais claras e articuladas", e indica que, "a partir de 1955, a relação entre esporte e nação se dá cada vez mais fora do Estado" (Archetti, 2001: 116).

O nacionalismo ligado ao esporte teria tocado o próprio Vargas. Ainda que não fosse grande entusiasta dos esportes, Vargas teria sentido sua força de identificação ao presenciar uma disputa do Circuito da Gávea, ${ }^{2}$ em 1934, como demonstra seu diário:

2 a 4 de outubro de 1934.

O dia 3 do corrente, aniversário da Revolução, não teve qualquer festividade. Parece até que passou esquecido. Observei-o com amargura. Apenas, nesse dia, tivemos a corrida de automóveis. Foi um espetáculo empolgante: grande multidão, pista difícil, corrida arriscada, alguns acidentes, vários que desistiram da prova em meio. Por fim, venceu um brasileiro. Como é forte o sentimento nacional! (...) Junto a mim estavam o embaixador argentino e algumas senhoras. Guardando a atitude de compostura exterior, eu imediatamente sentia-me comovido, com receio até de que me saltassem lágrimas se vencesse um estranho. E eu mesmo me analisava, tomado daquela emoção estranha que procurava reprimir (Vargas, 1995, vol. 1: 331).

Tal proximidade entre o fenômeno esportivo e a identidade nacional pode ser encontrada em diversas ocasiões nos dois regimes, seja através das celebrações cívicas ou de espetáculos esportivos organizados pelo governo.

Uma das marcas do esporte no governo Vargas foi a ausência de grandes eventos esportivos internacionais no país, com exceção do Circuito da Gávea. O governo brasileiro chegou a se candidatar para sediar uma Copa do Mundo, mas com a eclosão da Segunda Guerra Mundial, o sonho dos dirigentes nacionais foi adiado até 1950, meses antes da eleição que traria Vargas de volta ao poder.

Ainda assim, os diversos confrontos internacionais da equipe brasileira que melhor simbolizava a nação, a seleção masculina de futebol, marcaram uma forte relação de identidade entre o povo, o esporte e a pátria. $\mathrm{O}$ futebol já era a modalidade mais popular do país anos antes da chegada de Getúlio ao poder. Em 1932, ao derrotar os uruguaios - então campeões do mundo - em pleno estádio 
Centenário, em Montevidéu, e conquistar a Copa Rio Branco, ${ }^{3}$ a seleção brasileira foi recebida de volta ao Rio de Janeiro como heroica representante da nação. Até mesmo Vargas, em seu diário, nota a festa de retorno dos jogadores, que desfilaram pela cidade: " 19 de dezembro de 1932: pela tarde, despachei com os ministros da Justiça e da Educação, e assisti ao desfile dos footballers brasileiros que regressavam vitoriosos de Montevidéo" (Vargas, 1995, vol. 1: 164).

O futebol havia se tornado, para os brasileiros, um símbolo da nação. A vitória nas quatro linhas eram conquistas da pátria. No entanto, as lutas internas do futebol brasileiro eram, por sua vez, como uma guerra civil, na medida em que dividiam as forças nacionais e evitavam futuros sucessos esportivos. A maior dessas divisões internas no futebol brasileiro ocorreu em 1933, com a cisão entre os clubes ditos amadores e os que se proclamavam profissionais, e ficou conhecida na época como "dissídio esportivo". Na verdade, essa divisão suplantou a questão "amadorismo x profissionalismo" em pouco tempo, e logo ficou evidente que a disputa interna no futebol brasileiro era a luta pela hegemonia no controle do esporte entre duas elites que caracterizavam as tensões existentes no regime de Getúlio Vargas. ${ }^{4}$

É nesse intervalo que a seleção brasileira disputa a Copa do Mundo de 1934. Na briga pelo comando do futebol brasileiro, a Confederação Brasileira de Desportos (CBD), como única representante nacional da Federação Internacional de Futebol (FIFA), passa a ditar as regras do jogo e deixa de fora todos os jogadores dos grandes clubes do Brasil ligados ao profissionalismo.

A Copa do Mundo de 1934 foi organizada em modelo de eliminatórias, com 16 times se enfrentando nas oitavas de final. Quem perdesse estava fora. O Brasil, assim como a Argentina - vice-campeã da Copa de 30 -, perdeu logo na estreia. Depois de um jogo bastante disputado, com Waldemar de Brito perdendo um pênalti, o Brasil não resistiu à seleção espanhola e perdeu o jogo por 3 a 1 . Eliminado com apenas uma partida, esta foi a pior Copa disputada pelo Brasil em todos os tempos.

Uma vez fora da Copa mais cedo do que o esperado, a seleção brasileira aproveitou para excursionar pela Europa e fazer propaganda do maior produto de exportação brasileiro - o café. A seleção jogou na Iugoslávia, na Espanha e em Portugal e, após três meses no estrangeiro, retornou ao país, sendo recebida sem muita festa.

Com o fim do dissídio em 1937, a seleção brasileira pôde disputar a Copa do Mundo de 1938 com seus principais jogadores. A Copa de 38, na França, deixaria ainda mais evidente a aproximação do "pai dos pobres" com o futebol. Além de conceder uma alta subvenção à delegação brasileira para as despesas com o campeonato, o presidente da República fez questão de cumprimentar os jogadores antes do embarque para a França, deixando clara a importância que o 


\section{Maurício Drumond}

título teria para o futuro da nação. Getúlio Vargas dispensou atenção especial à grande estrela da seleção, Leônidas da Silva. Leônidas, conhecido também como Diamante Negro, era o maior ídolo do futebol brasileiro. Ao lado de Getúlio Vargas e de Orlando Silva, foi um dos brasileiros mais populares durante a Era Vargas. ${ }^{5}$

Enquanto a bola rolava na Europa, no Brasil o governo colhia os frutos da boa campanha do time nacional. As vitórias da seleção alimentavam o orgulho cívico do povo. Não foi por acaso que a partir da Copa de 1938 a principal festa cívica do regime varguista, $o 1^{\circ}$ de Maio, passou a ser realizada em estádios de futebol, em especial o de São Januário, no Rio de Janeiro.

De volta à casa, após a derrota na polêmica semifinal, que relegou o Brasil à terceira colocação, a seleção foi recebida como campeã moral do campeonato. Ao desembarcar no Rio de Janeiro, foi recebida por milhares de pessoas nas ruas. O comércio fechou as portas e os jogadores desfilaram em carro aberto, saudados como heróis nacionais. "Queira ou não queira a FIFA, somos campeões do mundo", publicava ofornal dos Sports na primeira página, no dia 20 de junho de 1938, logo após a vitória contra a Suécia. A manchete mostrava o espírito com que os jogadores brasileiros seriam recepcionados em seu regresso.

Era exatamente por esse clima festivo, de louvor à pátria, que o esporte fascinava os líderes do regime. A mobilização gerada pelo esporte - majoritariamente pelo futebol, no Brasil - foi também vivenciada durante as disputas dos campeonatos Sul-Americanos, da Copa Roca e da Copa Rio Branco, ${ }^{6}$ durante toda a Era Vargas.

A Argentina peronista, ao contrário do Brasil da Era Vargas, foi sede de diversas competições internacionais. $\mathrm{O}$ auge dessas competições foi, ao certo, $\mathrm{o}$ primeiro campeonato Pan-Americano, realizado em Buenos Aires no ano de 1951. Durante esses jogos, Perón parecia ser onipresente, assistindo a praticamente todas as modalidades e estando presente às disputas de medalhas mais importantes, tendo sempre suas fotos nas páginas dos jornais. Esses jogos foram, na realidade, a confirmação pública do sucesso da política esportiva peronista.

Os Jogos Pan-Americanos tiveram sua abertura no recém-inaugurado Estádio Presidente Perón, uma das maiores marcas da tão alardeada benfeitoria peronista ao esporte. ${ }^{7}$ Em grande cerimônia, Perón fez um breve discurso, declarando abertos os jogos. Ao final da competição, a Argentina figurava no primeiro lugar do quadro de medalhas, com 68 medalhas de ouro e 150 no total. Os Estados Unidos, já uma potência nos esportes, ficaram em segundo lugar, com 44 medalhas de ouro e 95 no total, bem abaixo do país anfitrião. Tal fato não passaria despercebido pela propaganda oficial e pela imprensa peronista.

Assim, a revista Mundo Deportivo ${ }^{8}$ alardeava as virtudes do esporte argentino sob a tutela de Perón, marcadas por uma "inquestionável superiorida- 
de" argentina sobre as outras nações do torneio, em especial a norte-americana. $O$ fato de a delegação americana não ter contado com sua força máxima na competição não era mencionado nas páginas esportivas do período. Ao contrário, o Mundo Deportivo exaltava os até então imbatíveis americanos, como forma de enaltecer ainda mais a conquista peronista. $O$ seguinte trecho de um editorial do período, intitulado "Victoria", é uma boa demonstração do sentimento que se buscava gerar com as vitórias no campo esportivo.

Os Primeiros Jogos Esportivos Pan-Americanos foram para a juventude argentina um motivo de legítimo orgulho, e para a cidadania, uma satisfação muito difícil de superar.

A juventude argentina venceu de forma inquestionável a todos seus oponentes no magno certame, e muito especialmente à delegação dos Estados Unidos, até agora imbatível em todas as competições de atletismo que haviam se apresentado.

Que poderoso milagre transformou a nossa juventude? Foi mudado o seu físico? Foi modificado seu temperamento? Foram transformadas suas idiossincrasias?

Nada disso.

Tudo se deve a apenas uma coisa. Ao General Perón, condutor de seu povo e esportista por excelência. À frente de sua juventude, pôde mudar o espírito, sua mística e seu sentimento. (...)

Ele fez milagre, e com essa juventude que há cinco anos nem sequer figurava nos resultados finais das provas atléticas internacionais, bateu os campeões do mundo.

Os inumeráveis triunfos obtidos pela representação nacional simbolizam o ressurgimento de um potencial físico e uma força moral digna da Nova Argentina que o General Perón forjou. (Mundo Deportivo, 22/03/1951: 26)

Assim, Perón aparece como principal causa não apenas do sucesso esportivo da nação, mas também da formação de um novo povo, com grande potencial físico e força moral, a chamada "Nova Argentina".

Além dos Jogos Pan-Americanos, várias outras competições esportivas foram organizadas em solo argentino. Entre elas, teve destaque o campeonato mundial de basquetebol, realizado também em Buenos Aires, no ano de 1950, no 


\section{Maurício Drumond}

qual o selecionado argentino sagrou-se campeão mundial, derrotando os Estados Unidos no jogo final. Apesar de a equipe americana estar representada pelos atletas de um time de segunda divisão, o Denver Chevrolet, a vitória argentina foi comemorada profusamente nas ruas da cidade. $\mathrm{O}$ basquete argentino continuou conquistando bons resultados internacionais após essa vitória, como a medalha de prata nos Jogos Pan-Americanos de 51, quando perdeu a final para os Estados Unidos por 57 a 51.

Outros esportes também foram palco de disputas internacionais em solo argentino. O autódromo 17 de Outubro 9 foi construído para receber o Grande Prêmio da Argentina de Fórmula 1, em um período no qual Juan Manuel Fangio se destacou no quadro internacional do automobilismo. ${ }^{10} \mathrm{O}$ boxe era também um esporte extremamente popular, e diversas lutas internacionais foram disputadas no Luna Park, principal arena fechada portenha. A nobre arte era uma das modalidades mais identificadas com Perón, visto que ele havia sido boxeador em sua juventude. E o governo peronista não poupava esforços para conseguir alçar o boxe nacional à condição de campeão mundial. Já no Pan-Americano de 51, o boxe argentino alcançou a medalha de ouro nas oito modalidades disputadas. $\mathrm{O}$ título mundial viria apenas em 1954, com Pascual Pérez, também conhecido como Pascualito, na categoria peso mosca, ao derrotar o japonês Yoshio Shirai em Tóquio. De acordo com Victor Lupo (2004: 314), as primeiras palavras de Pascualito Pérez na rádio foram: "Ganhei para Perón, para minha pátria e para a Argentina".

Já o futebol argentino não esteve presente em muitas competições internacionais. Devido à greve dos jogadores profissionais argentinos em 1948, e ao êxodo de muitos desses atletas para a Colômbia, a seleção argentina não participou do campeonato Sul-Americano de 1949 e da Copa do Mundo de $1950 .{ }^{11}$ Sua volta a disputas internacionais ocorreu em 1951, com uma excursão pela Europa, onde perderia para a Inglaterra, em Wembley, por 2 a 1, e ganharia da Irlanda por $1 \mathrm{a} 0$. Dois anos mais tarde, os ingleses retornaram a cortesia e foram à Argentina disputar duas partidas contra a seleção de Perón. No primeiro jogo, em 14 de maio de 1953, os argentinos venceram os ingleses por 3 a 1 no estádio do River Plate. ${ }^{12} \mathrm{O}$ segundo jogo, realizado no domingo, dia 17 , foi cancelado decorridos 23 minutos do primeiro tempo, devido à chuva torrencial que se abatia sobre Buenos Aires. No entanto, a primeira vitória foi suficiente para a imprensa argentina exaltar a identidade argentina através do "estilo criollo", criativo e artístico, contra o estilo frio e mecânico, mas eficiente, dos ingleses.

Uma vitória cabal, justa, ampla, histórica, que poderia se resumir (...) na fisionomia dos primeiros gols: mecânica fria mas 
oportuna e exata, dos ingleses; inspiração quase artística, agudeza de critério, sublimação da obra coletiva, dos argentinos (...). (apud DiGiano, 1999)

A imprensa e o rádio foram os principais meios de transmissão da ideologia oficial. Tanto no Brasil como na Argentina, foram alvo de forte censura e controle do Estado, o que fez com que a maior parte desses veículos seguisse a orientação do governo. Assim, a imprensa peronista, como a varguista no Brasil, procurava realçar, através do esporte, a característica de um "novo povo". O esporte representaria a pátria, e as batalhas travadas no campo esportivo eram travadas simbolicamente por toda a nação. As vitórias exaltavam as virtudes nacionais, e o sucesso esportivo era visto como reflexo do sucesso nacional. Até mesmo as derrotas, quando resultantes de um embate digno, e muitas vezes vistas como injustas ou mesmo desleais, eram percalços que, quando superados, aproximavam ainda mais o povo de seu símbolo pátrio, de sua seleção, de sua nação. O esporte se tornava então um forte elemento de identificação nacional, difundido por todo território pátrio através das ondas do rádio, das páginas dos jornais ou das telas do cinema, como teria apontado o próprio Getúlio Vargas: "Com os instrumentos próprios de educação extraescolar, hoje tão diferentes - cinema, teatro, desportos -, será possível levar a todas as populações do Brasil o culto da Pátria e de suas tradições gloriosas" (apud Capelato, 1998: 219).

\section{O esporte como propaganda política}

Observamos que, na utilização do esporte como propaganda política, os governos de Vargas e Perón buscaram uma identificação, por vezes direta, entre o regime e o sucesso obtido no campo esportivo. Outro ponto importante a ser notado era a formação eugênica da juventude de uma nova nação, que daria origem a um novo homem, um novo cidadão.

A ligação do Estado com a juventude através do esporte tinha como um de seus objetivos formar o "novo homem nacional" através da educação física, moral, cívica e eugênica. A nova "raça brasileira" idealizada pelos intelectuais estado-novistas era representada por esses jovens sadios. Dessa forma o regime se apresentava como produtor de uma nova estirpe de brasileiros, de uma raça bem constituída, forte e perseverante. Em um período no qual a própria ideia da formação e da identidade do povo brasileiro estava sendo redefinida, acreditava-se que o Estado teria papel fundamental em moldar a nova geração de brasileiros, transformando-os na base de um país a progredir. 


\section{Maurício Drumond}

A ligação do esporte com a juventude e sua ênfase na unidade nacional teria uma grande importância para os ideólogos do governo. Assim, tal ideal se refletia junto aos periódicos, onde termos como "civismo", "pátria" e "nação" inundavam as páginas esportivas. Como exemplo, pode-se observar uma promoção criada pelo fornal dos Sports, de Mario Filho, em conjunto com O Globo, de onde ainda era editor de esportes, e o Clube de Regatas Flamengo, então presidido por Bastos Padilha, seu cunhado. Os jornais publicavam, diariamente, um selo. Os selos deveriam ser preenchidos pelos jovens com uma frase onde se encontrassem as palavras "Flamengo" e "Brasil".

Segundo o jornal, a promoção idealizada pelo clube carioca "plasmará uma juventude eugênica, pronta a servir a pátria em todos os domínios da actividade humana", uma vez que no esporte "se acham entrelaçados dois bellos sentimentos: o amor pátrio e o amor pelo club que visa o ideal de todo ser humano: 'mens sana in corpore sano"' (Fornal dos Sports, 02/03/1937: 4). As frases vencedoras do concurso possuíam forte teor nacionalista, tais como: "O Flamengo ensina: amar o Brasil sobre todas as coisas", de Marcio Lyra - 13 anos, primeiro colocado; "Brasil! O valor do teu povo construiu um Flamengo", de Léa de Almeida -7 anos, em segundo; e "Flamengo, o futuro da mocidade do Brasil", de Antonio Vieira - 14 anos, em terceiro (Fornal dos Sports, 04/03/1937: 4).

$\mathrm{Na}$ argentina peronista, as crianças deveriam ser iniciadas nas práticas esportivas ainda na escola. Em 1953, o Estado estabeleceu uma organização de estudantes secundaristas chamada Unión de Estudiantes Secundários (UES), que reunia estudantes sob o pretexto da prática de esportes e atividades físicas. Em seu curto tempo de existência sob o governo peronista, a UES se tornou rapidamente uma entidade de alcance nacional e edificou instalações por todo o país, como o teatro Juan Domingo Perón, na capital federal. Como pode ser visto até mesmo pelo nome do teatro da entidade estudantil, a UES foi formada já como um braço do partido justicialista junto à juventude argentina, e desde seus primórdios teve uma atuação pública muito intensa de apoio ao presidente. Em todos os eventos públicos de apoio a Perón, a UES marcava sua presença, e todos os periódicos ligados ao governo clamavam o apoio da juventude ao presidente. $\mathrm{O}$ retrato de Perón, assim como algumas de suas frases famosas, estava presente em todas as sedes da UES. Seu hino falava que "os jovens seguem os passos de Perón" e que "sentem seus corações queimarem com a chama luminosa de Perón" (apud Rein, 1998: 66). Não é de se estranhar então que, na ocasião da autoproclamada "Revolução Libertadora", que tirou Perón do poder, cercearam-se as atividades da UES, banindo vários de seus membros de competições esportivas em território nacional.

A ligação do Estado argentino com a juventude e a prática esportiva não teve início apenas com a UES, em 1953. Desde o início de seu governo, Perón es- 
teve próximo do esporte. No entanto, foi através de sua esposa Eva Perón que o Estado argentino alcançou seu maior grau de identificação com o fenômeno. Conhecida também como "Evita”, "Mãe dos Humildes”, "Dama da Esperança” e "Chefe Espiritual da Nação", Eva Perón assumiu a liderança da ação social, no país, em especial após a criação da Fundação Eva Perón.

A Fundação Ajuda Social Maria Eva Duarte de Perón foi criada em 1948, e mais tarde teria seu nome alterado para Fundação Eva Perón (Lupo, 2004: 182). Também conhecida apenas como A Fundação (La Fundación), era administrada pelo ministro da Fazenda de Perón, Ramón Cereijo ${ }^{13}$ e, apesar de ser, teoricamente, uma entidade não-governamental, era intimamente ligada ao partido justicialista e aos seus principais líderes. Contando com arrecadação ligada ao governo federal, a Fundação logo se tornou uma grande ferramenta de propaganda peronista, exaltando a imagem de Evita, que viria a se tornar um verdadeiro mito argentino. Dessa forma, Eva Perón assumiu a liderança da ação social no país e sua imagem alcançou uma grandeza ímpar no regime, tornando-se uma figura quase sagrada. Sua imagem passou a ser tão importante quanto a do próprio Perón, como pode ser percebido através do slogan popular "Perón cumpre, Evita dignifica" (Aringoli, 2006: 208).

Além de toda a sua atuação social em favor das crianças, dos jovens e dos necessitados, Evita desempenhou um forte papel em prol esportes no país, atuando junto a seu marido na promoção da "Nova Argentina", especialmente entre as crianças. Através da Fundação, o governo promovia campeonatos infantis de diversos esportes, conhecidos como Campeonatos Infantis Evita.

Esses campeonatos receberam grande atenção da mídia peronista, especialmente do semanário Mundo Deportivo, uma vez que, além de associarem o regime à pratica esportiva infantil, auxiliavam na criação de um sentimento de identificação e integração nacional, ao promover a disputa direta entre crianças de todas as províncias em um "campeonato argentino". Raanan Rein cita um dos primeiros números do semanário infantil do grupo Haynes, ${ }^{14}$ Mundo Infantil, que se referia aos Campeonatos Evita dizendo:

O Campeonato Evita irá realizar o sonho de professores e líderes: ele irá unir a juventude argentina através de um laço que transcenderá divisões locais, e mesmo provinciais, porque a voz do esporte é gritante, poderosa, envigorante e eletrificante. Neste quadro, todos se sentirão como iguais, todos pensarão da mesma maneira. (Rein, 1998: 59)

O mesmo sentimento de unidade nacional foi apontado por Carlos Aloé ${ }^{15}$ em seu editorial em Mundo Deportivo (09/02/1950: 22), ao escrever que "É 


\section{Maurício Drumond}

a juventude da Nova Argentina, (...) enchendo seu peito de orgulho patriótico e querendo demonstrar - no começo de sua vida - que já é digna, que já é forte e grande e que neles bem está a esperança da Pátria".

É também importante notar que, além do sentimento nacional gerado pelas competições, estas também carregavam a imagem dos governantes consigo. Tal era a ligação do regime, em especial de Eva Perón, com a competição que, entre as várias equipes envolvidas, diversas possuíam nomes que faziam referência ao peronismo, como "17 de Outubro" ou "Evita, Estrela da Manhã" (Mundo Deportivo, 20/03/1952). Antes dos jogos, os participantes cantavam as marchas "Evita Capitana" e "Los Muchachos Peronistas", além da marcha oficial do campeonato, na qual diziam: "A Evita devemos nosso clube, por isso lhe guardamos nossa gratidão. Nós cumprimos os ideais, nós cumprimos a Missão, da Nova Argentina de Evita e Perón" (Rein, 1998: 64).

Mas os Campeonatos Infantis Evita não se resumiam ao futebol. Logo outras modalidades esportivas passaram a ser disputadas, como basquete, atletismo e polo aquático. E em cada um desses, Perón e sua esposa eram presenças garantidas no jogo final, seja dando o pontapé inicial nas partidas de futebol, distribuindo medalhas, ou saindo em diversas fotos que seriam publicadas nos mais diversos jornais argentinos no dia seguinte.

A ligação de Vargas com o fenômeno esportivo não era nem mesmo próxima à conquistada por Perón. Vargas tentou estabelecer um vínculo entre sua filha Alzira Vargas e a seleção brasileira de 1938, nomeando-a madrinha da seleção nacional. No entanto, tal relação não pode ser comparada à importância de Evita para o esporte argentino, o que não teve paralelos na história do esporte brasileiro, e talvez na de nenhum outro país.

Outra grande diferença entre essa relação de Vargas e Perón era a imagem esportiva do presidente. Além de não possuir um tipo atlético, Getúlio não tinha sua imagem identificada com a prática esportiva. Através de algumas entradas em seu diário, Getúlio se declara um golfista amador. Em 5 de junho de 1938, escreveu: "Pela manhã, fui ao golf no Itanhangá" (Vargas, 1995, vol. 2: 138), e em 22 de janeiro de 1939, "Fui ao golf, como de costume" (Vargas, 1995, vol. 2: 194). No entanto, a imagem de um presidente golfista não é algo com o que a grande massa da população possa se identificar, ou que a faça identificá-lo como esportista. Ainda mais visto que o golfe não era um esporte consumido pela grande maioria da população brasileira.

$\mathrm{Na}$ Argentina, a imagem esportiva construída por Perón foi quase diametralmente oposta. A identificação do presidente com o esporte atingiu proporções tão grandes, que ele era conhecido como "O Primeiro Desportista". Como publicou o semanário Mundo Deportivo (29/04/1954: 4), "Perón e esporte se confundem como causa e efeito". 
Durante sua juventude, Perón dizia ter praticado tiro, polo, natação, futebol, esqui, basquetebol, esgrima e boxe. Campeão argentino de esgrima de 1918 a 1928 (Massarino, 2001), Perón fora selecionado para participar dos Jogos Olímpicos de 1924 pela Argentina, mas teve sua autorização negada pelo então ministro da Guerra, Augustín P. Justo (Lupo, 2004: 190). Além de grande esgrimista, dizia-se também que Perón havia sido um grande boxeador amador em sua juventude. Em um número do semanário Mundo Deportivo que contou com um fascículo sobre a história do boxe na Argentina, o então presidente da República foi mencionado entre muitos outros pugilistas, profissionais e amadores, que haviam marcado a história da modalidade. Sobre seu nome, o artigo destaca:

Separamos propositalmente um nome, entre os vários que contribuíram para a maior difusão e melhor compreensão do boxe entre o povo. Esse nome é o do hoje Presidente da nação, general Juan Perón, que, naqueles tempos, estimulou com seu entusiasmo e dedicação os princípios do esporte, e terminou por deixar uma obra de caráter permanente com a fundação do Boxing Club de Paraná. (...) A História do boxe na Argentina não pode, portanto, esquecer o general Juan Perón. (Mundo Deportivo, 20/04/1954: 59)

Vê-se assim que a imagem do presidente era profundamente ligada aos esportes. De fato, o Primeiro Esportista argentino era identificado com praticamente todas as modalidades. Em outra ocasião, já em 1954, o semanário esportivo ligado ao governo dedica um número praticamente inteiro ao general. Em um de seus artigos, destaca toda a versatilidade e excelência do primeiro mandatário no esporte.

Perón conheceu a juventude nas quadras de esporte, as quais frequentou como atleta integral. O boxeador das turmas da academia se transformou no esgrimista de estilo clássico, e nessa prodigiosa multiplicação de personalidades que forja essa fase, passou a ser basquetebolista pioneiro e futebolista sagaz, tanto como automobilista fervoroso, motociclista capaz. (Mundo Deportivo, 22/04/1954: 27)

Além de ser um sportsman exemplar, Perón era também visto como o grande guia esportivo da nação, assim como o responsável por todo o seu sucesso. A associação do regime com o esporte atingiu proporções tão grandes na Argentina, que várias praças esportivas foram batizadas em homenagem ao primeiro 


\section{Maurício Drumond}

mandatário e sua esposa. Em setembro de 1950, o Racing inaugurou seu novo estádio, o já mencionado Estádio Presidente Perón. Já o Club Atlético Sarmiento teve seu estádio aberto ao público em julho de 1951, sob o nome de Estádio Eva Perón. Outras modalidades também foram contempladas com a construção de suas praças, a maioria com nomes ligados ao peronismo, como o velódromo Presidente Perón, em Palermo, e o autódromo 17 de Outubro, em Buenos Aires. Foi comum, durante o período peronista, dar a campeonatos, troféus e centros esportivos nomes peronistas ou associados ao movimento justicialista.

A construção de estádios também foi uma realidade no governo de Getulio Vargas, mesmo que em escala muito menor. Dentre as praças esportivas construídas no Brasil, destaca-se o estádio municipal do Pacaembu, inaugurado em 27 de abril de 1940. Este estádio, aliado ao estádio de São Januário, no Rio de Janeiro, seria um dos grandes palcos do espetáculo do poder do governo Vargas. Os estádios brasileiros serviram de palco para várias festas cívicas. Entre tais festas destacavam-se o aniversário de Vargas (19 de abril), o Dia da Independência (7 de setembro) e, em especial, o Dia do Trabalhador ( $1^{\circ}$ de maio).

\section{As festas cívicas}

Os esportes e as festas públicas funcionavam como a teatralização de uma imagem de "nação feliz e longeva". Ao mesmo tempo, essas celebrações cívicas comemoravam o "novo". Um novo governo, um novo regime, um novo país, fosse este o Estado Novo de Vargas ou a Nova Argentina de Perón. Nesse sentido, Claudia Schemes (2005: 34) aponta esse caráter de ruptura com o antigo dessas festas, afirmando: "A festa cívica reforça a imagem do poder, comemorando a morte do passado - o velho - e a instauração do novo - o futuro". A autora destaca que o novo tempo marcado por Getúlio e Perón trazia consigo a ideia de ruptura com um passado arcaico e atrasado. E era através de uma nova geração de brasileiros e argentinos que esse passado seria superado, sob a condução de seus líderes, que se encontravam acima das disputas que dividiam a sociedade.

Essa nova geração tinha sua ligação com o esporte ressaltada através da construção de uma "nova raça", tendo em vista o velho ideal de mens sana in corpore sano. Tal ideal era constantemente relembrado por Vargas e Perón em seus discursos ou em suas propagandas oficiais. Como apontou Perón em discurso durante uma competição esportiva:

Seja nossa homenagem para as glórias do esporte que nos acompanham, para os campeões, para todos os desportistas que estão construindo a Nova Argentina que desejamos, de homens sãos, ro- 
bustos e fortes. Porque fazem nações fortes, os povos sãos e vigorosos (apud Schemes, 2005: 112).

A formação dessa nova geração tinha nas festas cívicas sua apoteose. No Brasil, festas cívicas como o Dia da Raça e o Dia da Juventude celebravam essa "nova raça brasileira" de maneira espetacular. Realizadas normalmente em estádios de futebol ou nas ruas da cidade, contavam com grandiosos desfiles de crianças e jovens uniformizados e ensaiados, em um majestoso teatro da grandiosidade pátria e de seu chefe, onipresente na festividade através de centenas de retratos distribuídos pelos participantes, que os ostentavam com orgulho.

As celebrações em estádios de futebol já ocorriam no Brasil desde o início do governo Vargas. Mas, após a instauração do Estado Novo, essas celebrações se intensificaram. As comemorações da Semana da Pátria - a semana do 7 de setembro - eram sempre recheadas de eventos e apresentações esportivas, algumas delas em estádios, principalmente em São Januário. A Hora da Pátria, celebrada no dia 7 de setembro, foi por vezes celebrada em estádios, assim como as festas do $1^{\circ}$ de Maio.

No Rio de Janeiro, o estádio do Fluminense também era utilizado. Sede da Escola de Educação Física, a praça esportiva era palco de diversas apresentações de seus alunos. Até mesmo o Dia do Marinheiro, em 1938, foi motivo de exibições militares e esportivas no estádio das Laranjeiras. Festas no Dia das Crianças, no Dia da Raça e na Semana da Pátria eram frequentemente celebradas com eventos esportivos. No entanto, a maior celebração Varguista era, certamente, o Dia do Trabalho.

No $1^{\circ}$ de Maio, Getúlio Vargas sempre participava da comemoração pública oficial, que por diversas vezes ocorreu no estádio de São Januário. O estádio ficava lotado de pessoas que se dirigiam de todos os cantos da cidade, em linhas especiais de ônibus e bondes que transportavam passageiros gratuitamente. A entrada no estádio era franca, tudo feito de modo a incentivar a presença popular nas arquibancadas do então maior estádio da capital brasileira. Getúlio adentrava o gramado do estádio em carro aberto, normalmente acompanhado do ministro do Trabalho e de alguns membros de seu gabinete. Tocava-se então o Hino Nacional, seguido de vários discursos e de desfiles de atletas militares e operários. Era grandioso o simbolismo do evento, que era transmitido pelo DIP para todo o país, além de ser traduzido para outros idiomas e retransmitido para o exterior. Nessas cerimônias, Vargas assinava publicamente algum decreto em benefício aos trabalhadores - como o que instituía o salário mínimo, assinado em 1940 - e se retirava do estádio de forma triunfal, sendo saudado pelo povo. 


\section{Maurício Drumond}

Em São Paulo, o estádio do Pacaembu tinha função similar à de São Januário na capital federal. Em geral sem a presença do presidente, que participava das celebrações no Rio de Janeiro, as festas do $1^{\circ}$ de Maio paulista também agregavam milhares de pessoas. ${ }^{16}$ Assim como no Rio de Janeiro, parte das arquibancadas era reservada para sindicatos, associações trabalhistas e grupos militares. As festas contavam com desfiles militares, exibição de pilotos da aeronáutica e partidas amistosas de futebol, envolvendo os melhores jogadores da cidade. Tudo sempre muito bem controlado, documentado e divulgado pelo DIP.

Já na Argentina, as festas cívicas eram realizadas de forma mais frequente nas ruas da cidade, em especial na Praça de Maio. Segundo Claudia Schemes (2005: 43),

as festas argentinas eram realizadas em diversas situações, como por exemplo, antes das eleições, depois de agitações políticas, nas datas mais importantes para o país e para o regime, ou quando Perón queria impressionar seus opositores com uma mostra pública de solidariedade popular.

Em festas como a de 17 de outubro, multidões se espremiam em frente à Casa Rosada, esperando por horas até que Perón e Evita aparecessem nos balcões da casa do governo. O casal presidencial era recebido com grandes ovações, gritos, emoção e clamor.

No entanto, tais festividades não costumavam contar com eventos esportivos. $\mathrm{O} 1^{\circ}$ de Maio peronista era celebrado com grandes desfiles pelas ruas de Buenos Aires, organizados pela CGT (Confederación General del Trabajo), com a participação de trabalhadores e militares em conjunto, encabeçados pelo presidente. Eles evoluíam pela Avenida de Mayo, da Praça do Congresso até a concentração na Plaza de Mayo, seguidos pelos discursos de Juan e Evita Perón.

A maior celebração pública esportiva em homenagem ao regime peronista foi, sem dúvida, um desfile organizado pela CADCOA (Confederação Argentina de Desportes - Comitê Olímpico Argentino) em abril de 1954. O desfile, realizado na Avenida Corrientes, uma das principais vias da capital argentina, contou com aproximadamente 50 mil atletas das mais variadas modalidades, como polo, hóquei, beisebol, luta, boxe, futebol, basquetebol, ciclismo e outros. Até mesmo Juan Manuel Fangio participou do desfile, pilotando sua Ferrari na ala dos automobilistas, assim como astros do futebol argentino, como Labruna e Loustau, entre outros. A multidão, formada por jovens e adultos, todos vestindo trajes esportivos, lotou a avenida. 
O desfile, um tipo de festa cívica desportiva, tinha como objetivo agradecer ao presidente da nação toda a ajuda que ele havia dado aos esportes nacionais. O clima festivo, de comemoração do sucesso pátrio e sua ligação com Perón, contando com o discurso de autoridades políticas e com exibições públicas da aeronáutica, aproximava-o de uma festa cívica, em comemoração de alguma data nacional.

Em um período no qual seu governo já apresentava fortes dissidências e mostrava sinais de enfraquecimento, o mundo esportivo buscava mostrar todo seu apoio ao seu grande líder, o Primeiro Desportista. Como divulgado pelo jornal Clarín,

Não faltou no desfile nenhum esporte. Todos estiveram dignamente representados, porque todos receberam da parte do general Perón a ajuda e o estímulo que necessitavam para desenvolver-se e alcançar os legítimos e orgulhosos triunfos que nossa juventude merecia por seu esforço, sua dedicação e sua dureza, triunfo que o povo argentino tem celebrado sempre com a íntima satisfação e o fervor patriótico que tinha direito de expressar. (...) O pólo e o ciclismo, o xadrez e a natação, o automobilismo e a equitação, o hipismo e o motociclismo, o futebol e o atletismo em suas diversas ramificações, assim como outras práticas e exercícios destinados a vigorar o corpo e a mente da raça. Clarín (22/04/1954: 3)

Esse desfile de esportistas argentinos, assim como os eventos esportivos das festas cívicas brasileiras, se utilizava do capital simbólico envolvido no esporte, tendo em vista associá-lo ao regime e a seus líderes. A associação entre o esporte e a festa cívica era mais uma ferramenta na promoção da simbiose esporte/Estado, além de contribuir para a formação do clima festivo e da sensação de progresso, ambos de fundamental importância para os governos de Vargas e Perón.

\section{O governo no esporte}

Como visto acima, o esporte foi uma importante ferramenta de propaganda política empregada pelos governos de Vargas e Perón. A propaganda varguista tinha no futebol sua maior fonte de elementos nacionalistas, fator derivado da supremacia dessa modalidade sobre as outras no Brasil. Mas isso não significa que os outros esportes fossem esquecidos e deixados de lado. Olhando mais a 


\section{Maurício Drumond}

fundo, pode-se mesmo constatar a tentativa governamental de se associar a outros esportes, como o automobilismo, no Circuito da Gávea, como visto anteriormente. Na Argentina, por outro lado, o futebol aparece como mais um esporte a ser estimulado e financiado pelo governo. Apesar de ser, como no Brasil, o esporte mais popular no país, outras modalidades esportivas ganharam tanta atenção quanto o futebol, com divulgação, infraestrutura e financiamentos.

Através da Lei 12.932, sancionada por Perón em 1946, que autorizava empréstimos para a construção de estádios, campos e instalações a centros esportivos através da Comissão Nacional Honorária de Fomento ao Esporte (Lupo, 2004: 38), o Estado argentino liberava vultosas somas para os clubes profissionais. O futebol não era o único esporte agraciado, mas no topo da lista se encontrava o Racing Club, que recebera do governo 16.700 .000 pesos. Outros clubes populares receberam também elevadas quantias, como o Club Atlético Boca Juniores, $\$ 10.000 .000$, o River Plate, $\$ 7.000 .000$, Vélez Sarsfield, $\$ 6.000 .000$, entre muitos outros. O total da verba de governo destinada aos clubes teria sido, de acordo com os números do semanário Mundo Deportivo (22/04/1954: 52-54), de 111.923.000 pesos.

No Brasil, o financiamento do governo aos grandes clubes já era praticado pelas autoridades, mas a partir da Revolução de 30 foi estendido a clubes menores, não apenas por parte do governo federal, como também por prefeitos, interventores ou outros órgãos governamentais (Pereira, 2000: 355, nota 173). Na ocasião das Olimpíadas de 1932, em Los Angeles, o governo negou auxílio financeiro à CBD. A entidade, que organizava a delegação brasileira para a competição, teve que angariar os recursos de forma alternativa, com bailes e outros eventos. Já na Copa do Mundo de 1938, último grande evento esportivo internacional do governo Vargas, a CBD contou com uma subvenção de 200:000\$000 (Pereira, 2000: 336).

Com ligações tão próximas do esporte, ambos os governos procuraram exercer um controle mais efetivo sobre a organização esportiva nacional. No governo Vargas, já se discutiam projetos acerca da “oficialização dos esportes" antes mesmo da instauração do Estado Novo. No entanto, apesar do pedido de Vargas pela aprovação de tais projetos na Câmara, a dita oficialização viria apenas em abril de 1941. No dia 16 desse mês foi publicado no Diário Oficial da União o decreto-lei que criava o Conselho Nacional de Desportos (CND), no Ministério da Educação e Saúde. O CND tinha como função "orientar, fiscalizar e incentivar a prática dos desportos em todo o país". ${ }^{17}$ Em outras palavras, o conselho detinha o controle quase total dos desportos, trazendo toda a organização esportiva nacional para a direta influência do Estado, para o interior de sua ordem corporativa.

O conselho detinha controle quase total também sobre as entidades esportivas. Os estatutos das confederações e das federações a elas filiadas tinham 
que ser aprovados pelo CND, que poderia propor ao ministro da Educação a criação ou a supressão de qualquer confederação. No tocante às competições internacionais, o Conselho Nacional de Desportos exercia um controle ainda mais rígido. A participação de qualquer clube ou entidade em uma competição internacional deveria ser previamente autorizada pelo CND. Caso o conselho decidisse pela participação de alguma equipe em um campeonato internacional, esta não poderia abster-se da convocação.

OCND também atuava junto ao governo federal na utilização do futebol para fins de propaganda. Como exemplo, pode-se citar o caso dos jogos em homenagem à Força Expedicionária Brasileira (FEB). Com a entrada do Brasil na II Guerra Mundial, a FEB se preparou para tomar parte no combate, em 1944. O CND organizou então um evento festivo para a despedida dos pracinhas. Foram promovidas duas partidas da seleção brasileira, uma na capital do país, em São Januário, e outra em São Paulo, no Pacaembu - os estádios de maior capacidade do país e de estreita ligação simbólica com o Estado. Os jogos da seleção brasileira contra o Uruguai eram, sem dúvida, um excelente chamariz, visto que as competições internacionais estavam estagnadas desde a entrada do Brasil na guerra, em agosto de 1942.

Em 14 de maio milhares de pessoas compareceram ao estádio de São Januário para o primeiro jogo entre brasileiros e uruguaios. O primeiro jogo, na capital de República, contou com a presença de importantes nomes do governo na tribuna de honra, como Oswaldo Aranha, Eurico Gaspar Dutra e Joaquim Salgado Filho, ministros do Exterior, da Guerra e da Aeronáutica, respectivamente; além de oficiais do governo uruguaio. $\mathrm{O}$ jogo foi precedido de muitas formalidades em homenagem ao Corpo Expedicionário Brasileiro. Quatro dias depois, no estádio do Pacaembu, efetuava-se o segundo confronto entre as seleções. Nem mesmo a confusão dentro de campo, com um zagueiro uruguaio sendo retirado de jogo, desacordado, ofuscou o sucesso do evento.

Na Argentina, foi com a criação do Conselho Nacional de Educação Física, com o Decreto Nacional $\mathrm{n}^{0} 34.817$, de 6 de novembro de 1947, que o governo ampliou ainda mais sua interferência nos assuntos esportivos. Atrelado diretamente ao Ministério da Guerra, esse conselho tinha a função de "dirigir, orientar, fomentar e fiscalizar tudo referente à Educação Física oficial e privada", compreendendo "a ginástica, os jogos e esportes, a recreação, o tiro esportivo, as colônias e acampamentos educativos e de férias e tudo o referente à medicina aplicada a Educação Física" (Lupo, 2004: 38). O mesmo Decreto Nacional $n^{\circ} 34.817$ incorporou a Confederação Argentina de Desportos - Comitê Olímpico Argentino (CADCOA) ${ }^{18}$ ao Conselho Nacional de Educação Física. Foi através do CADCOA que o governo peronista controlou os esportes profissionais. 


\section{Maurício Drumond}

Esse controle era, no entanto, feito de forma um pouco mais velada do que no caso brasileiro. Isso pode ser visto com uma declaração de Perón, após assinar, em 1954, um decreto que designava ao Ministério da Educação a responsabilidade pela direção da educação física e à CADCOA a responsabilidade pela gestão de todo o esporte na nação: "Eu farei no esporte o que me diga a CAD" (Lupo, 2004: 110). No entanto, é importante ressaltar que desde 1952, dois anos antes dessa declaração, o presidente da CADCOA era designado diretamente pelo próprio presidente, ou seja, por Perón, fazendo com que o governo mantivesse o poder sobre a entidade.

Diversas outras organizações esportivas estiveram sob a influência do governo peronista. A Associação do Futebol Argentino (AFA) teve diversos presidentes ligados ao regime durante os anos do governo de Perón. Sob intervenção militar e dirigida pelo general Eduardo J. Avalos até 1946, a AFA foi, por curto tempo, gerida por Pedro Canaveri, até que Ramón Cereijo convenceu Perón da necessidade de colocar "alguém de muita confiança em seu lugar" (Gambini, 2007: 440). Assim, em 1947, assumiu Oscar L. Nicolini, administrador geral de Correios da Nação, que permaneceu no cargo até 1949, quando assumiu a pasta de ministro de Comunicações do governo. Algumas semanas após sua saída, assumiu a presidência da AFA Valentin Suarez, dirigente do Independiente e subdiretor nacional de Trabalho, outra figura ligada ao movimento peronista.

Assim como tantas outras dimensões da sociedade argentina, os esportes também foram "desperonizados" com o fim do regime em 1955. A grande maioria das realizações peronistas na área do esporte, assim como seus meios de intervenção, foi extinta, ou profundamente alterada, com o fim do regime. Já no Brasil, foi apenas com a Constituição de 1988 - 43 anos após o fim do Estado Novo e 47 anos após sua criação - que o Conselho Nacional de Desportos foi extinto, dando fim a uma importante era da organização do esporte brasileiro.

\section{Considerações finais}

Ao se produzir um estudo comparado entre os governos de Vargas e Perón, deve-se atentar não apenas para suas semelhanças. Na verdade, suas diferenças por vezes dizem muito mais do que os pontos em comum, que podem saltar aos olhos de um observador mais descuidado. Nas dessemelhanças apresentadas em ambos os casos estudados, pode-se buscar preciosas informações sobre as particularidades de cada regime, e na comparação destas com suas similitudes, um quadro maior se abre para o entendimento do objeto através de novas perspectivas. Na utilização do esporte pela política varguista e peronista, o caso aqui estudado, esta realidade não poderia ser diferente. 
A apropriação do esporte, por parte dos dois governos, foi um dos diversos elementos mobilizados na busca de formação de uma identidade nacional, assim como a educação, as artes, o cinema e a música, entre tantos outros. Vê-se assim que o esporte foi também um importante fator na construção da imagem de uma nova pátria. Esta, legitimada pelos espectadores no estádio, pelos leitores das páginas esportivas dos jornais e pelos ouvintes do rádio, que se punham a torcer pelas cores de seu país - seja no futebol, no boxe, no basquete ou em outra modalidade -, sugeria uma identidade que poderia ser compartilhada coletivamente. Assim, cabia à propaganda política oferecer à multidão de torcedores e ao espectador solitário a sensação de pertencer a algo, de poder compartilhar das mesmas emoções das pessoas envolvidas no espetáculo esportivo em toda a nação.

É inegável que a proximidade de Perón com o esporte foi maior do que a de Getúlio Vargas. É possível que o regime varguista, por não depender do apoio popular no processo eleitoral, uma vez que a constituição do Estado Novo cerceava todas as liberdades políticas, buscasse no esporte apenas mais uma estratégia de legitimação do novo regime. Já Perón, que mantinha em seu país a aparência do estado de direito, necessitava do apoio popular em todo o processo eleitoral, e o esporte seria mais um forte aliado no processo de participação das massas.

Dessa forma, Perón teria maior necessidade do capital simbólico que o esporte poderia oferecer. Denominado de "Primeiro Desportista", assim como de "Primeiro Mandatário" e de "Primeiro Trabalhador", o presidente argentino fez de sua ligação com a prática esportiva um de seus principais trunfos em sua aproximação com o povo argentino, assim como construiu um clima festivo de sucesso nacional.

A figura de Eva Perón, esposa do presidente, foi uma das maiores difusoras da imagem de consciência social do governo justicialista. Através da Fundação Eva Perón, milhares de "descamisados" recebiam ajuda do governo. Foi sob a égide da Fundação e de Evita que foi organizado um dos maiores instrumentos utilizados pelo governo no âmbito esportivo, o Campeonato Infantil Eva Perón.

Assim como Perón, Vargas buscou no esporte um apoio para a implementação de um novo ideário nacionalista no esporte. Apesar de não ter sua imagem tão próxima ao esporte como no caso argentino, Getúlio também soube utilizar os esportes, em especial o futebol, como uma ferramenta de propaganda política do regime. A utilização pública dos centros de espetáculos esportivos foi uma das principais estratégias de aproximação simbólica entre seu governo e o esporte.

Vargas e Perón tratavam de utilizar elementos contidos no esporte visando a tornar os grandes ídolos esportivos e as vitórias por eles conquistadas em símbolos, do Estado Novo e da Nova Argentina, presentes no cotidiano. Apesar 
do caráter controlador dessas representações arranjadas pelos regimes, o clima festivo gerado pelo esporte pretendia ocultar a faceta autoritária de seus governos.

Assim, percebe-se que o caráter mobilizador do esporte era instrumentalizado, buscando a legitimação dos regimes estabelecidos. Reunindo os espectadores em torno de um mesmo ícone que fosse capaz de representar uma nova nação, consolidavam a ideia de uma nova sociedade, que visava a se construir e se consolidar sob uma imagem harmônica e homogênea. Casos plenamente observáveis, com suas peculiaridades, nos exemplos argentino e brasileiro de Juan Perón e Getúlio Vargas.

Notas

1. Para maiores informações sobre a utilização política do esporte por governos fascistas, ver Arnaud e Riordan (1998), Riordan e Kruger (1999) e Agostino (2002).

2. O Circuito da Gávea foi uma prova internacional de automobilismo realizada nas ruas do Rio de Janeiro, organizada irregularmente entre 1933 e 1954. Para maiores informações acerca do automobilismo na Era Vargas e sobre o Circuito da Gávea, ver Melo (2009).

3. A Copa Rio Branco era um troféu disputado em confrontos entre a seleção brasileira e a uruguaia.

4. Para maiores informações sobre o dissídio esportivo, ver Drumond (2006 e 2008a) e Souza (2008).

5. Sobre a popularidade de Leônidas da Silva, ver Souza (2008) e Ribeiro (1999).

6. A Copa Rio Branco era disputada em confrontos entre a seleção brasileira e a seleção argentina de futebol.

7. O estádio Presidente Perón, do Racing Club, foi construído com verbas do go- verno, como parte de um conjunto de amplos créditos cedidos pelo governo a grandes clubes esportivos (Drumond, 2008c: 83-84).

8. Mundo Deportivo era uma revista esportiva semanal de forte cunho peronista criada em 1949 como oposição ao tradicional periódico El Gráfico, que não era totalmente fiel ao governo (Archetti, 2001: 116). Para maiores informações sobre o caráter peronista de Mundo Deportivo e sua oposição ao El Gráfico, ver Drumond (2008b).

9. Em 17 de outubro de 1945, milhares de pessoas se reuniram na Plaza de Mayo para pedir a libertação do então coronel Perón, que havia sido preso por um grupo de militares. Perón foi solto no mesmo dia e discursou à multidão do balcão central da Casa Rosada, de onde anunciou que concorreria às eleições de fevereiro de 1946, quando se tornou presidente argentino. Durante o período peronista, diversas arenas esportivas receberam nome em homenagem ao regime.

10. Fangio é considerado um dos maiores pilotos de Fórmula 1 de todos os tempos, 
tendo sido pentacampeão da modalidade em 1951, 54, 55, 56 e 57, além de ter alcançado a segunda posição em 1950.

11. Maria Graciela Rodriguez (1997) e Gilberto Agostino (2002: 167) também apontam como fator decisivo para a ausência da seleção argentina de futebol em campeonatos importantes do período o temor de um possível fracasso que se refletiria na imagem de sucesso esportivo do regime.

12. Segundo Gilberto Agostino, os ingleses teriam jogado essa partida, realizada em uma quinta-feira, com grande número de jogadores reservas, poupando os titulares para o segundo jogo, a ser realizado no domingo seguinte (Agostino, 2002: 170).

13. O ministro da fazenda de Perón, Ramón Cereijo, era um grande fã de esportes, em especial do Racing Club de Avellaneda, o mesmo time para o qual, dizia-se, torcia Perón. Durante os anos peronistas, o Racing foi um dos times mais fortes do futebol argentino, tendo sido tricampeão argentino em 1949-50-51. Devido ao apoio recebido pelos nomes do governo, o Racing ganhou o apelido de Deportivo Cereijo (Rein, 1998: 58).

\section{Referências bibliográficas}

AGOSTINO, Gilberto. Vencer ou morrer: futebol, geopolítica e identidade nacional. Rio de Janeiro: Faperj-Mauad, 2002.

ANDERSON, Benedict. Comunidades imaginadas: reflexões sobre a origem e expansão do nacionalismo. Lisboa: Edições 70, 2005.

ARCHETTI, Eduardo P.El potrero, la pistay el ring: las pátrias del deporte argentino. Bue-
14. O grupo Haynes era um império periodístico que passou a ser majoritariamente controlado pelo governo argentino durante o governo de Perón. Entre suas publicações podemos apontar o jornal $E l$ Mundo e as revistas Mundo Argentino, Caras y Caretas, Mundo Radial, Mundo Deportivo e Mundo Peronista.

15. Diretor do grupo Haynes e editor de Mundo Deportivo, Carlos Aloé era homem de confiança de Juan Perón. Assumiu o governo da província de Buenos Aires em 1952.

16. Em 1944, Vargas celebrou o $1^{\circ}$ de maio no estádio do Pacaembu, em São Paulo.

17. Decreto-Lei n. 3.199, de 14 de abril de 1941. Diário Oficial da União, 16 de abril de 1941. Para maiores informações sobre o Decreto-Lei que criara o CND, ver Manhães (1986).

18. A Confederação Argentina de Desportos (CAD) e o Comitê Olímpico Argentino (COA) foram unidos em uma mesma entidade em 31 de maio de 1927, pelo Decreto 74, assinado pelo presidente Marcelo Torcuato de Alvear (Lupo, 2004: 123).

nos Aires: Fondo de Cultura Economica, 2001.

ARINGOLI, Guilhermo D'Arino. La propaganda peronista: 1943-1955. Ituzaingó: Maipue, 2006.

ARNAUD, Pierre \& RIORDAN, James. Sport and International Politics: The Impact of 
Fascism and Communism on Sport. Oxon: Taylor \& Francis, 1998.

CAPELATO, Maria Helena R. Multidões em cena: propaganda política no Varguismo e no peronismo. Campinas: Papirus, 1998.

DIGIANO, Roberto. Peronismo y fútbol: el triunfo sobre Inglaterra en 1953. Lecturas: Educación Física y Deportes, n. 17, 1999. Disponível em: <www.ef deportes.com>. Acesso em: 10 de março de 2009.

DRUMOND, Maurício. Os gramados do Catete: futebol e política na Era Vargas (1930-1945). In: SILVA, Francisco Carlos Teixeira \& SANTOS, Ricardo Pinto. Memória social dos esportes. Futebol e politica: a construção de uma identidade nacional. Rio de Janeiro: Mauad. 2006, p. 107-132.

Esporte e política no Estado Novo. In: PONTES JR., Geraldo \& PEREIRA, Victor Hugo Adler (org.). O velho, o novo, $o$ reciclável Estado Novo. Rio de Janeiro: Instituto de Letras da UERJ, 2008a.

- Imprensa esportiva e propaganda política no peronismo: uma comparação entre "El Gráfico" e "Mundo Deportivo". Lecturas: Educación Física y Deportes, Buenos Aires, n. 117, 2008b. Disponível em: $<$ www.efdeportes. com $>$. Acesso em: $10 \mathrm{de}$ abril de 2009.

- Nações em jogo: esporte e propaganda politica em Vargas e Perón. Rio de Janeiro: Apicuri, 2008c.

GAMBINI, Hugo. Historia del peronismo: $E l$ poder total (1943-1951). Buenos Aires: Vergara, 2007.

LUPO, Victor. Historia política del deporte argentino (1610-2002). Buenos Aires: Corregidor, 2004.

LYRA FILHO, João. Introdução à psicologia dos desportos. Rio de Janeiro: Record, 1983.

MANHÃES, Eduardo Dias. Política de esportes no Brasil. Rio de Janeiro: Graal, 1986.
MASSARINO, Marcelo. "Por Perón y por la pátria". Un análisis del discurso peronista y deporte (1946-1955). Lecturas: Educación Física y Deportes, Buenos Aires, $\mathrm{n}$. 46, 2001. Disponível em: <www. efdeportes.com $>$. Acesso em: 18 de fevereiro de 2009.

MELO, Victor Andrade de. Antes de Fittipaldi, Piquet e Senna: o automobilismo no Brasil (1908-1954). Motriz, Rio Claro, vol. 15, n. 1, 2009, p. 104-115.

PEREIRA, Leonardo Affonso de Miranda. Footballmania: uma história social do futebol no Rio de faneiro (1902-1938). Rio de Janeiro: Nova Fronteira, 2000.

REIN, Raanan. "El Primer Deportista": The Political Use and Abuse of Sport in Peronist Argentina. The International Fournal of the History of Sport, vol. 15, n. 2, 1998, p. 54-76.

RIBEIRO, André. O diamante eterno: biografia de Leônidas da Silva. Rio de Janeiro: Gryphus, 1999.

RIORDAN, Jim \& KRUGER, Arnd. The International Politics of Sport in the $20^{\text {th }}$ Century. Oxon: Taylor \& Francis, 1999.

RODRIGUEZ, Maria Graciela. El deporte como politica de Estado (periodo 1945-1955). Lecturas: Educación Fúsica y Deportes. Buenos Aires, n. 4, 1997. Disponível em: <www. efdeportes. com>. Acesso em: 10 de novembro de 2007.

SCHEMES, Claudia. Festas cívicas e esportivas: um estudo comparativo dos governos Vargas (1937-1945) e Perón (1946-1955). Novo Hamburgo: Feevale, 2005.

SOUZA, Denaldo Alchorne. O Brasil entra em campo: construções e reconstruções $d a$ identidade nacional (1930-1947). Pinheiros: Annablume, 2008.

VARGAS, Getúlio. Diário. 2 vols. São Paulo: Siciliano; Rio de Janeiro: FGV, 1995. 


\section{Resumo}

Durante a primeira Era Vargas no Brasil (1930-1945), e durante os dois primeiros mandatos de Perón (1946-1952 e 1952-1955) na Argentina, o esporte foi um importante instrumento político. $O$ controle estatal sobre $o$ esporte e sua utilização pelos meios de propaganda política visavam a criar um elo de identificação nacional entre esporte e governo. Por esta razão, este artigo estabelece uma relação entre o esporte e a política nos dois governos estudados, comparando manifestações públicas - eventos esportivos, comemorações cívicas -, a produção dos principais órgãos da imprensa esportiva especializada e produções culturais do Estado, que envolvem o esporte e a ideologia oficial dos regimes.

Palavras-chave: história política, história do esporte, história comparada, varguismo, peronismo, esporte

\section{Abstract \\ During the first Vargas Era in Brazil (1930-1945), and the first two administrations of Perón in Argentina (1946-1952 and 1952-1955), sport was an important political instrument. The control of the State over sport and its use by political propaganda aimed at creating a link of national identification between sport and government. For that reason, this article establishes a relationship between sport and politics in the two governments, comparing their public events - sports events, civic celebrations -, the production of their main sports periodicals, and State cultural productions, involving sport and the official ideology of the regimes.}

Key words: political history, sports history, comparative history, varguism, peronism, sport

\section{Résumé}

Pendant le premier gouvernement Vargas au Brésil (1930-1945), et les deux premiers mandats de Perón en Argentine (1946-1952 et 1952-1955), le sport a été un important instrument politique. Le contrôle de l'État sur le sport et son usage par la propagande politique avaient le but de créer un lien d'identification nationale entre sport et gouvernement. Pour cette raison, cet article établit un rapport entre sport et politique dans les gouvernements analysés, en comparant leurs événements publics - événements sportifs, célébrations civiques -, la production de leurs principaux journaux de sports et les productions culturelles de l'État, liées au sport et à l'idéologie officielle des régimes.

Mots-clés: histoire politique, sports histoire, histoire comparée, varguisme, péronisme, sport 